\title{
Clinical Study \\ Risk Factors for Hepatitis C Virus Transmission Obscure in Nigerian Patients
}

\author{
Olive Obienu, ${ }^{1}$ Sylvester Nwokediuko, ${ }^{1}$ Abraham Malu, ${ }^{2}$ and Olufunmilayo A. Lesi ${ }^{3}$ \\ ${ }^{1}$ Gastroenterology Unit, Department of Medicine, University of Nigeria Teaching Hospital, Ituku/Ozalla, PMB 01129 Enugu, Nigeria \\ ${ }^{2}$ Department of Medicine, Jos University Teaching Hospital, Jos, Nigeria \\ ${ }^{3}$ Department of Medicine, Lagos University Teaching Hospital, Lagos, Nigeria
}

Correspondence should be addressed to Sylvester Nwokediuko, scnwokediuko@yahoo.com

Received 21 March 2011; Accepted 23 May 2011

Academic Editor: Simon P. Horslen

Copyright () 2011 Olive Obienu et al. This is an open access article distributed under the Creative Commons Attribution License, which permits unrestricted use, distribution, and reproduction in any medium, provided the original work is properly cited.

\begin{abstract}
Aim. To determine the prevalence of anti-HCV and risk factors associated with HCV infection in Nigerians. Materials and Method. Patients attending a general outpatient clinic were administered a structured questionnaire on the risk factors for HCV infection. They were also tested for anti-HCV using a third generation enzyme-linked immunosorbent assay. Result. The seroprevalence of anti-HCV was $4.7 \%$. Among the risk factors evaluated, none was found to be significantly associated with anti-HCV seropositivity. Conclusion. The risk factors associated with HCV infection in Nigerian patients are obscure. This warrants further studies on the epidemiology of this important cause of liver disease.
\end{abstract}

\section{Introduction}

Hepatitis C virus (HCV) infection continues to be a major disease burden on the world. In 1999, the World Health Organisation (WHO) estimated a worldwide prevalence of about $3 \%$ with the virus affecting 170 million people worldwide [1]. A more recent estimate puts the prevalence at $2.2 \%$ corresponding to about 130 million HCV-positive persons worldwide [2]. Because many countries lack data, this estimate is based on weighted averages for regions rather than individual countries.

In the industrialized countries, HCV accounts for $20 \%$ of cases of acute hepatitis, $70 \%$ of cases of chronic hepatitis, $40 \%$ of cases of end stage cirrhosis, $60 \%$ of cases of hepatocellular carcinoma (HCC), and 30\% of liver transplants [3, 4]. An estimated $27 \%$ of cirrhosis and $25 \%$ of hepatocellular carcinoma worldwide occur in HCV-infected people [5].

The most efficient transmission of HCV is through large or repeated direct percutaneous exposure to blood (of transfusion or transplantation from infectious donors and injecting drug use) [6]. HCV is less efficiently transmitted by single small-dose percutaneous exposure (e.g., accidental needle sticks) $[6,7]$ or by mucosal exposures to blood or serum-derived fluids (e.g., birth to an infected mother and sexual intercourse with an infected partner) $[6,8,9]$. The high transmission rate through illicit intravenous drug use (IVDU) explains why the prevalence of HCV among people who acquired human immunodeficiency virus (HIV) through IVDU reaches $90 \%$ [10].

The risk factors for HCV transmission in Nigeria have not been properly characterized. Even in the western world where some risk factors have been identified, recent studies indicate that the global epidemiology of $\mathrm{HCV}$ has been changing $[11,12]$. This scenario has compounded efforts at developing strategies for HCV screening. This study was designed to determine the prevalence of HCV infection in Nigerian patients and to determine the risk factors associated with it.

\section{Materials and Methods}

This study was a cross-sectional seroprevalence study involving adult patients attending the General out-patient clinic of the University of Nigeria Teaching Hospital, Ituku-Ozalla. The study was approved by the Hospital Research Ethics Committee, and the participants gave informed consent. 
TABLE 1: Anti-HCV serostatus of patients.

\begin{tabular}{lccc}
\hline Group & Anti-HCV positive (\%) & Anti-HCV negative (\%) & Total \\
\hline Males & $6(3.3)$ & $177(96.7)$ & 183 \\
Females & $11(6.2)$ & $166(93.8)$ & 177 \\
Total & $17(4.7)$ & $343(95.3)$ & 360 \\
\hline
\end{tabular}

TABLE 2: Risk factors for HCV infection.

\begin{tabular}{|c|c|c|c|c|c|c|}
\hline Risk factor & $\begin{array}{c}\text { Anti-HCV positive } \\
(n=17)\end{array}$ & $\begin{array}{l}\text { Anti-HCV negative } \\
\quad(n=343)\end{array}$ & Relative risk & Odds ratio & $\chi^{2}$ & $P$ value \\
\hline Blood transfusion & 2 & 36 & 1.115 & 1.121 & 0.022 & 0.882 \\
\hline Uvulectomy & 2 & 37 & 1.46 & 1.495 & 0.013 & 0.91 \\
\hline Tattooing & 0 & 2 & 0.000 & 3.93 & 0.99 & 0.75 \\
\hline Multiple sexual partners & 3 & 59 & 1.025 & 1.026 & 0.002 & 0.97 \\
\hline Sharing of toothbrush & 4 & 78 & 1.033 & 1.035 & 0.004 & 0.95 \\
\hline Sharing of razor blades & 5 & 101 & 1.000 & 1.000 & 0.000005 & 1.00 \\
\hline Sharing of shaving sticks & 1 & 19 & 1.059 & 1.062 & 0.003 & 0.95 \\
\hline Injections from quacks & 2 & 40 & 1.008 & 1.009 & 0.00013 & 0.99 \\
\hline Scarification markings & 1 & 17 & 1.176 & 1.187 & 0.026 & 0.87 \\
\hline Occupational exposure & 0 & 5 & 0.000 & 1.784 & 0.248 & 0.62 \\
\hline Intravenous drug use & 0 & 0 & - & - & - & - \\
\hline
\end{tabular}

Patients who had symptoms and signs suggestive of liver disease were excluded. Each participant was administered a structured questionnaire containing the putative risk factors for $\mathrm{HCV}$ transmission.

Venous blood ( $5 \mathrm{mLs}$ ) was obtained from the participants and tested for antibody to HCV (anti-HCV) using a third generation enzyme-linked immunosorbent assay (ELISA) manufactured by DRG International Inc., USA. This test kit has a sensitivity of $95 \%$ and specificity of $97.5 \%$.

The data was analyzed and the results expressed as means and proportions. Differences between means and proportions were determined using student's $t$-test and chisquared test, respectively. A $P$ value of $\leq 0.05$ was considered statistically significant.

\section{Results}

Three hundred and sixty (360) patients participated in the study. They consisted of 183 males (50.8\%) and 177 females (49.2\%). Their ages ranged between 19 years and 75 years (mean $=36.4 \pm 9.4$ years). Seventeen patients tested positive for anti-HCV (4.7\%). The mean age of the anti-HCVpositive patients was $36.0 \pm 8.1$ years while the mean age of the anti-HCV-negative patients was $36.8 \pm 9.9$ years. The difference between the means was not statistically significant $(P=0.9526)$. Table 1 illustrates the anti-HCV serostatus and gender distribution of the patients. The putative risk factors were marginally more frequent in the anti-HCV seropositive patients compared to the anti-HCV-negative group, but none reached statistical significance (Table 2 ).

\section{Discussion}

The seroprevalence of anti-HCV in this study was $4.7 \%$. This finding is comparable to the results of similar studies across the continent [13-21]. However, none of the putative risk factors evaluated in this study showed any significant association with anti-HCV seropositivity.

Transfusion-associated HCV infection was a predominant worldwide risk before HCV testing became available. It has been virtually eliminated in those countries that implemented routine HCV testing of donors [22], but in others, receipt of blood transfusion remains an important source of infection. Some countries continue to use commercial donors to supplement their blood supplies [23]. In Nigeria, the low risk of transmission through blood transfusion may be related to the low prevalence of HCV in the general populace, coupled with the fact that Nigeria is successfully implementing a national blood safety programme led by Safe Blood for Africa Foundation (SBFA) to fight the spread of HIV/AIDS [24]. An estimated $3.6 \%$ of Nigerians are living with HIV and AIDS [25], which translates into about 3.3 million people. HCV coinfection with hepatitis $B$ virus (HBV) and/or HIV has been described in some studies in Nigeria [26, 27].

Certain high-risk behaviours and practices which are prevalent in African societies have been shown to play some role in Hepatitis B virus (HBV) transmission. These include scarification marks, sharing of sharp body-piercing instruments like razor blades, sharing of toothbrushes, and instruments for native uvulectomies [28]. Uvulectomy is practiced in Nigerian communities as treatment for sore throat. It is usually carried out by local healers in very unhygienic environments without any consideration for infection control. The instruments used are not usually sterilized. The procedure carries other risks like bleeding, anemia, sepsis, and transmission of other pathogens including HIV and HBV. Deaths have resulted from such procedures [29]. 
These high-risk behaviours and practices do not seem to contribute significantly to the spread of HCV. The reason for this may also be related to the low prevalence of HCV in the populations involved. Another reason is the fact that HBV is approximately 10 times more infectious than $\mathrm{HCV}[30,31]$.

The risk factors for HCV infection may be unidentified in a significant proportion of patients in many parts of the world. In a study in Iran, the risk factors for infection could not be identified in $20 \%$ of cases [32]. In other studies, risk factors accounting for infection remain unknown in 10$40 \%$ of patients with acute or chronic Hepatitis C [33, 34]. A study conducted recently at a Northern California Liver centre between 2001 and 2008 showed that Asian-Americans are more likely to present with unidentifiable risk exposure [35]. The researchers concluded that the commonly known risk factors for HCV may be more appropriate for risk assessment for Caucasians and Hispanics but not for AsianAmericans. These findings pose major implications for developing strategies for HCV screening in our increasingly culturally diverse population.

In conclusion, the seroprevalence of anti-HCV in a population of Nigerians attending a general out-patient clinic is $4.7 \%$. The risk factors associated with anti-HCV seropositivity are largely obscure, and this calls for more studies into the epidemiology of HCV infection in order to develop effective strategies for screening.

\section{References}

[1] W. H. O., "Global surveillance and control of hepatitis C. Report of a WHO consultation organized in collaboration with the Viral Hepatitis Prevention Board Antwerp, Belgium," Journal of Viral Hepatitis, vol. 6, pp. 35-47, 1999.

[2] Y. Hutin, M. E. Kitler, G. J. Dore et al., "Global burden of disease (GBD) for hepatitis C," Journal of Clinical Pharmacology, vol. 44, no. 1, pp. 20-29, 2004.

[3] J. P. Benhamou, J. Rodes, H. Alter et al., "EASL international consensus conference on hepatitis C, Paris, 26-28 February 1999: consensus statement," Journal of Hepatology, vol. 30, no. 5, pp. 956-961, 1999.

[4] "Consensus conference. Treatment of hepatitis C. guidelines," Gastroentérologie Clinique et Biologique, vol. 26, pp. B312B320, 2002.

[5] J. F. Perz, G. L. Armstrong, L. A. Farrington, Y. J. Hutin, and B. P. Bell, "The contributions of hepatitis B virus and hepatitis $\mathrm{C}$ virus infections to cirrhosis and primary liver cancer worldwide," Journal of Hepatology, vol. 45, no. 4, pp. 529-538, 2006.

[6] "Recommendations for prevention and control of hepatitis $\mathrm{C}$ virus (HCV) infection and HCV-related chronic disease. Centre for disease control and prevention," MMWR-Recommendations and Reports, vol. 47, pp. 1-39, 1998.

[7] V. Puro, N. Petrosillo, and G. Ippolito, "Risk of hepatitis $\mathrm{C}$ seroconversion after occupational exposure in healthcare workers. Italian Study Group on occupational risk of HIV and other bloodborne infections," American Journal of Infection Control, vol. 23, pp. 273-277, 1995.

[8] E. A. Roberts and L. Yeung, "Maternal-infant transmission of hepatitis C virus infection," Hepatology, vol. 36, no. 5, supplement 1, pp. S106-S113, 2002.
[9] N. A. Terrault, "Sexual activity as a risk factor for hepatitis C," Hepatology, vol. 36, no. 5, supplement 1, pp. S99-S105, 2002.

[10] M. S. Sulkowski and D. L. Thomas, "Hepatitis C in the HIVinfected person," Annals of Internal Medicine, vol. 138, no. 3, pp. 197-207, 2003.

[11] J. I. Esteban, S. Sauleda, and J. Quer, "The changing epidemiology of hepatitis C virus infection in Europe," Journal of Hepatology, vol. 48, no. 1, pp. 148-162, 2008.

[12] P. Fabris, V. Baldo, T. Baldovin et al., "Changing epidemiology of HCV and HBV infections in Northern Italy: a survey in the general population," Journal of Clinical Gastroenterology, vol. 42, no. 5, pp. 527-532, 2008.

[13] M. Imoru, C. Eke, and A. Adegoke, "Prevalence of hepatitis B surface antigen ( $\mathrm{HBsAg}$ ), hepatitis $\mathrm{C}$ virus (HCV) and human immunodeficiency virus (HIV) among blood donors in Kano State, Nigeria," Journal of Medical Laboratory Science, vol. 12, pp. 59-63, 2003.

[14] O. Erhabor, O. A. Ejele, and C. A. Nwauche, "The risk of transfusion-acquired hepatitis- $\mathrm{C}$ virus infection among blood donors in Port Harcourt: the question of blood safety in Nigeria," Nigerian Journal of Clinical Practice, vol. 9, no. 1, pp. 18-21, 2006.

[15] B. B. D. Koate, F. I. Buseri, and Z. A. Jeremiah, "Seroprevalence of hepatitis C virus among blood donors in Rivers State, Nigeria," Transfusion Medicine, vol. 15, no. 5, pp. 449-451, 2005.

[16] D. Z. Egah, B. M. Mandong, D. Iya et al., "Hepatitis C Virus antibodies among blood donors in Jos, Nigeria," Annals of African Medicine, vol. 3, pp. 35-37, 2004.

[17] S. C. Nwokediuko, O. G. Ibegbulam, and T. Ugwu, "Hepatitis $\mathrm{C}$ Virus seroprevalence in blood d onors at the University of Nigeria Teaching Hospital Enugu," Journal of College of Medicine, vol. 12, pp. 85-88, 2007.

[18] Z. A. Jeremiah, B. Koate, F. Buseri, and F. Emelike, "Prevalence of antibodies to hepatitis $\mathrm{C}$ virus in apparently healthy Port Harcourt blood donors and association with blood groups and other risk indicators," Blood Transfusion, vol. 6, no. 3, pp. 150155, 2008.

[19] O. Azeez-akande, A. Sarki, E. E. Wokedi, A. Olabode, and P. Alabi, "Seroprevalence and risk factors of Hepatitis C virus in patients and blood donors in Kano, Nigeria," African Journal of Clinical and Experimental Microbiology, vol. 11, pp. 170-173, 2010.

[20] C. I. Mboto, I. E. Andy, O. I. Eni, and A. P. Jewell, "Prevalence, sociodemographic characteristics and risk factors for hepatitis C infection among pregnant women in Calabar municipality, Nigeria," Hepatitis Monthly, vol. 10, no. 2, pp. 116-120, 2010.

[21] E. S. Amadi, C. E. Ononiwu, N. Aballa, S. A. Oladimeji, F. A. Ancke, and C. O. Aneke, "The epidemiology of hepatitis $\mathrm{C}$ virus infection among patients attending the federal dental clinic, Enugu," Trends in Medical Research, vol. 4, no. 4, pp. 91-95, 2009.

[22] M. P. Busch, S. A. Glynn, S. L. Stramer et al., "A new strategy for estimating risks of transfusion-transmitted viral infections based on rates of detection of recently infected donors," Transfusion, vol. 45, no. 2, pp. 254-264, 2005.

[23] W. Hladik, P. Kataaha, J. Mermin et al., "Prevalence and screening costs of hepatitis C virus among Ugandan blood donors," Tropical Medicine and International Health, vol. 11, no. 6, pp. 951-954, 2006.

[24] “Safe Blood Programs-Nigeria," 2011, http://www.safebloodinternational.org/. 
[25] UNGASS Country Report Nigeria, 2010.

[26] S. M. Agwale, L. Tanimoto, C. Womack et al., "Prevalence of HCV coinfection in HIV-infected individuals in Nigeria and characterization of HCV genotypes," Journal of Clinical Virology, vol. 31, supplement 1, pp. S3-S6, 2004.

[27] J. A. Otegbayo, B. O. Taiwo, T. S. Akingbola et al., "Prevalence of hepatitis B and C seropositivity in a Nigerian cohort of HIVinfected patients," Annals of Hepatology, vol. 7, no. 2, pp. 152156, 2008.

[28] S. C. Nwokediuko, "Risk factors for hepatitis B virus transmission in Nigerians. A case-control study," The Internet Journal of Gastroenterology, vol. 10, no. 1, 2010.

[29] A. O. Olaosun, K. O. Ojemakinde, A. A. Raji, T. O. Adedeji, and S. O. Adebola, "Death of a child with leukemia subjected to uvulectomy," The Internet Journal of Third World Medicine, vol. 4, no. 2, 2007.

[30] C. Weinbaum, R. Lyeria, and H. S. Margolis, "Centre for disease control and prevention. Prevention and control of infections with hepatitis viruses in correctional settings. Centre for disease control and prevention," MMWR-Recommendations and Reports, vol. 52, pp. 1-36, 2003.

[31] C. Weinbaum, I. Williams, and E. E. Mast, "Centre for disease control and prevention. Recommendations for identification and public health management of persons with chronic hepatitis B virus infection," MMWR-Recommendations and Reports, vol. 57, pp. 1-20, 2008.

[32] S. M. Alavian, B. Gholami, and S. Masarrat, "Hepatitis C risk factors in Iranian volunteer blood donors: a case-control study," Journal of Gastroenterology and Hepatology, vol. 17, no. 10, pp. 1092-1097, 2002.

[33] S. Zeuzem, G. Teuber, J. H. Lee, B. Rüster, and W. Kurt Roth, "Risk factors for the transmission of hepatitis C," Journal of Hepatology, vol. 24, no. 2, pp. 3-10, 1996.

[34] R. A. Pondé, "Hidden hazards of HCV transmission," Medical Microbiology and Immunology, vol. 200, no. 1, pp. 7-11, 2011.

[35] E. Y. Ho, N. B. Ha, H. Mindie, and H. Nguyen, "Risk factors for Hepatis $\mathrm{C}$ acquisition are more likely to be unidentifiable in Asian-Americans compared to Caucasians or Hispanics (prospective study)," in Proceedings of the Digestive Disease Week (DDW '09), Chicago, Ill, USA, May 2009, abstract M1779. 


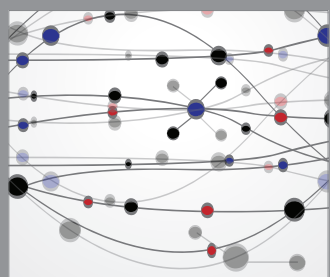

The Scientific World Journal
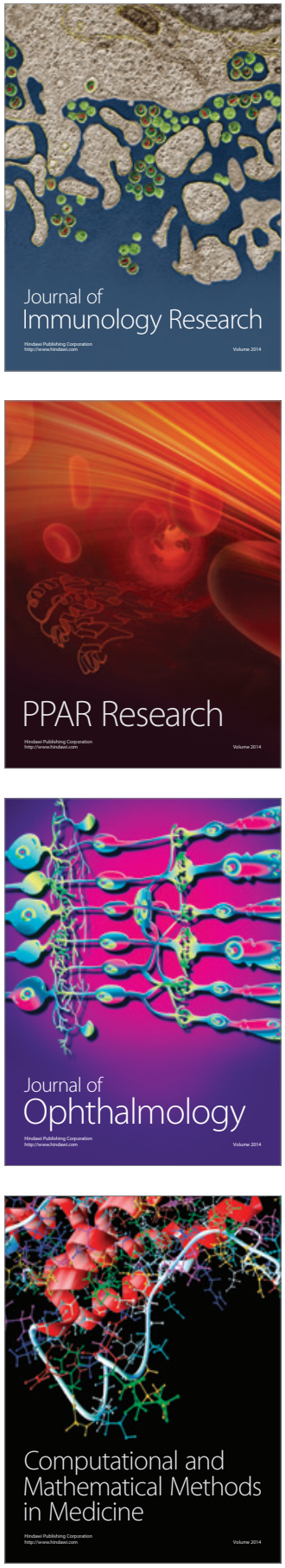

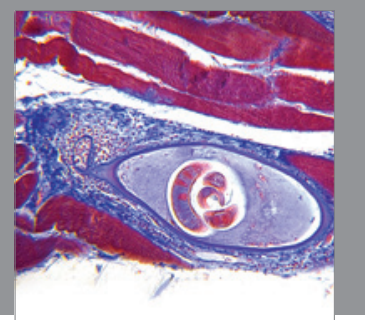

Gastroenterology

Research and Practice
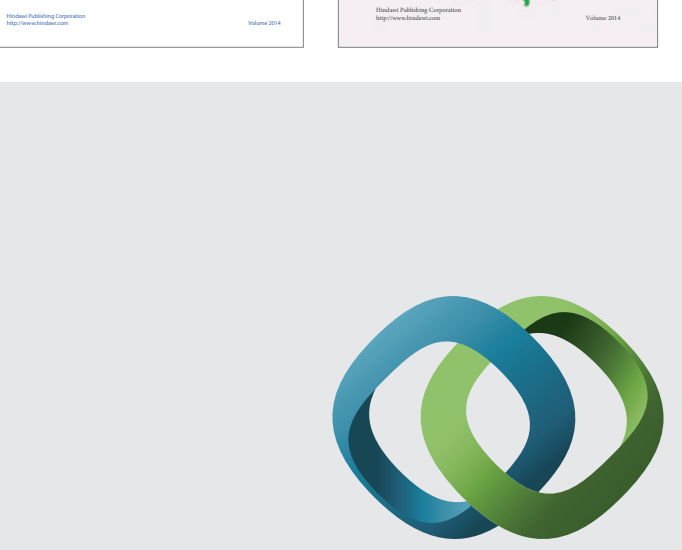

\section{Hindawi}

Submit your manuscripts at

http://www.hindawi.com
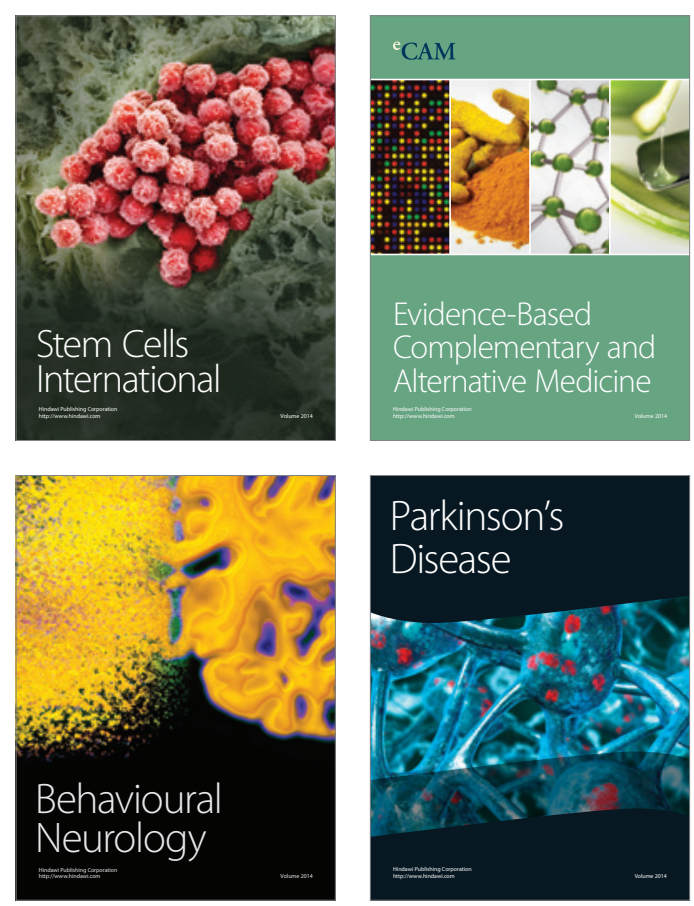

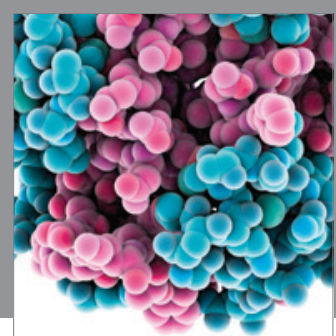

Journal of
Diabetes Research

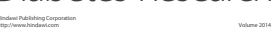

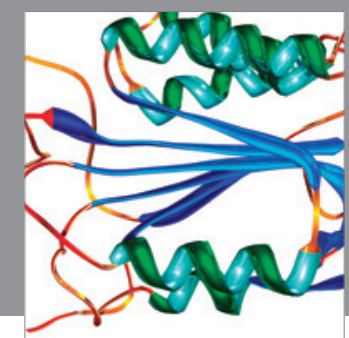

Disease Markers
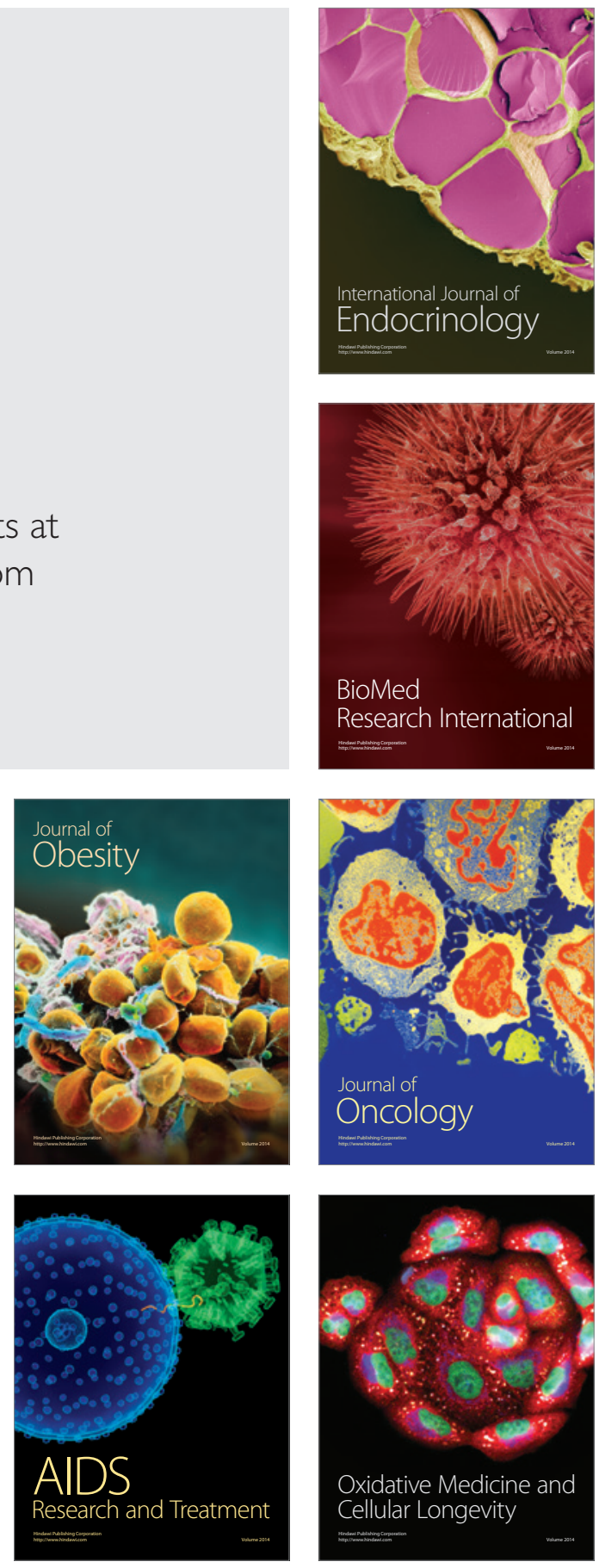